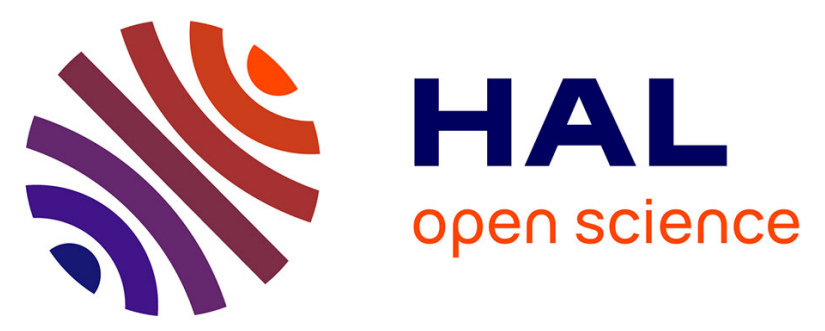

\title{
Interleukin-6 activates arginine vasopressin neurons in the supraoptic nucleus during immune challenge in rats
}

Karine Palin, Marie L. Moreau, Julie Sauvant, Hélène Orcel, Agnès Nadjar, Anne Duvoid-Guillou, Jennifer Dudit, Alain Rabié, Françoise Moos

\section{- To cite this version:}

Karine Palin, Marie L. Moreau, Julie Sauvant, Hélène Orcel, Agnès Nadjar, et al.. Interleukin-6 activates arginine vasopressin neurons in the supraoptic nucleus during immune challenge in rats. AJP - Endocrinology and Metabolism, 2009, 296 (6), pp.E1289-E1299. 10.1152/ajpendo.90489.2008 . hal-02659072

\section{HAL Id: hal-02659072 \\ https://hal.inrae.fr/hal-02659072}

Submitted on 30 May 2020

HAL is a multi-disciplinary open access archive for the deposit and dissemination of scientific research documents, whether they are published or not. The documents may come from teaching and research institutions in France or abroad, or from public or private research centers.
L'archive ouverte pluridisciplinaire HAL, est destinée au dépôt et à la diffusion de documents scientifiques de niveau recherche, publiés ou non, émanant des établissements d'enseignement et de recherche français ou étrangers, des laboratoires publics ou privés. 
Karine Palin, Marie L. Moreau, Julie Sauvant, Hélène Orcel, Agnès Nadjar, Anne Duvoid-Guillou, Jennifer Dudit, Alain Rabié and Françoise Moos

Am J Physiol Endocrinol Metab 296:1289-1299, 2009. First published Mar 3, 2009;

doi:10.1152/ajpendo.90489.2008

You might find this additional information useful...

This article cites 51 articles, 10 of which you can access free at:

http://ajpendo.physiology.org/cgi/content/full/296/6/E1289\#BIBL

This article has been cited by 1 other HighWire hosted article:

The clinical challenge of SIADH--three cases

N. van der Lubbe, C. J. Thompson, R. Zietse and E. J. Hoorn

NDT Plus, November 1, 2009; 2 (suppl_3): iii20-iii24.

[Abstract] [Full Text] [PDF]

Updated information and services including high-resolution figures, can be found at:

http://ajpendo.physiology.org/cgi/content/full/296/6/E1289

Additional material and information about AJP - Endocrinology and Metabolism can be found at: http://www.the-aps.org/publications/ajpendo

This information is current as of September 2, 2010 . 


\title{
Interleukin-6 activates arginine vasopressin neurons in the supraoptic nucleus during immune challenge in rats
}

\author{
Karine Palin, ${ }^{1 *}$ Marie L. Moreau, ${ }^{1 *}$ Julie Sauvant, ${ }^{1}$ Hélène Orcel, ${ }^{2}$ Agnès Nadjar, ${ }^{1}$ Anne Duvoid-Guillou, ${ }^{2}$ \\ Jennifer Dudit, ${ }^{1}$ Alain Rabié, ${ }^{2}$ and Françoise Moos ${ }^{1}$ \\ ${ }^{1}$ Institut National de la Recherche Agronomique, Unité mixte de recherche (UMR) 1286, PsyNuGen, Centre National de la \\ Recherche Scientifique (CNRS), UMR 5226, Université de Bordeaux, IFR8 Neurosciences, F-33076 Bordeaux; ${ }^{2}$ CNRS UMR \\ 5203, Institut de Génomique Fonctionnelle, Pharmacologie Moléculaire, Institut National de la Santé et de la Recherche \\ Médicale, U661, Université de Montpellier, F-34094, Montpellier, France
}

Submitted 4 June 2008; accepted in final form 25 February 2009

Palin K, Moreau ML, Sauvant J, Orcel H, Nadjar A, Duvoid-Guillou A, Dudit J, Rabié A, Moos F. Interleukin-6 activates arginine vasopressin neurons in the supraoptic nucleus during immune challenge in rats. Am J Physiol Endocrinol Metab 296: E1289-E1299, 2009. First published March 3, 2009; doi:10.1152/ajpendo.90489.2008.-The increase of plasma arginin-vasopressin (AVP) release, which translates hypothalamic AVP neuron activation in response to immune challenge, appears to occur independently of plasma osmolality or blood pressure changes. Many studies have shown that major inflammatory mediators produced in response to peripheral inflammation, such as prostaglandin (PG)- $\mathrm{E}_{2}$ and interleukin (IL)-1 $\beta$, excite AVP neurons. However, in vivo electrical activation of AVP neurons was still not assessed in relation to plasma AVP release, osmolality, or blood pressure or to the expression and role of inflammatory molecules like PG-E 2 , IL-1 $\beta$, IL-6, and tumor necrosis factor- $\alpha(\mathrm{TNF} \alpha)$. This study aims at elucidating those factors that underlie the activation of AVP neurons in response to immune stimulation mimicked by an intraperitoneal injection of lipopolysaccharide (LPS) in male Wistar rats. LPS treatment concomittanlty decreased diuresis and increased plasma AVP as well as AVP neuron activity in vivo, and these effects occurred as early as $30 \mathrm{~min}$. Activation was sustained for more than $6 \mathrm{~h}$. Plasma osmolality did not change, whereas blood pressure only transiently increased during the first hour post-LPS. PG- $E_{2}$, IL- $1 \beta$, and TNF $\alpha$ mRNA expression were raised $3 \mathrm{~h}$ after LPS, whereas IL-6 mRNA level increased 30 min post-LPS. In vivo electrophysiological recordings showed that brain IL-6 injection increased AVP neuron activity similarly to peripheral LPS treatment. In contrast, brain injection of anti-IL-6 antibodies prevented the LPS induced-activation of AVP neurons. Taken together, these results suggest that the early activation of AVP neurons in response to LPS injection is induced by brain IL-6.

lipopolysaccharide induced-hypothalamic vasopressin neuron activation; brain cytokines; diuresis; plasma osmolality; blood pressure

ESSENTIALLY RELEASED BY ACTIVATED NEURONS of the hypothalamo-neuropituitary complex, the plasma neurohormone arginine vasopressin (AVP) has functional significance in body fluid homeostasis and maintenance of arterial pressure (7). AVP neurons of the paraventricular (PVN) and supraoptic (SON) nuclei are well known to be activated in response to osmotic and volume dehydrations and to decrease in blood pressure $(26,37,46)$. AVP neurons can also be activated in response to peripheral inflammation, as attested by the increase in AVP circulating levels after peripheral injection of lipopoly-

* These authors have contributed equally to this work.

Address for reprint requests and other correspondence: K. Palin, Laboratoire PsyNuGen, Université de Bordeaux 2, CNRS UMR5226, INRA UMR1286, IFR8 Neurosciences, Bâtiment UFR de pharmacie, 146 rue Léo Saignat, Bordeaux, F-33076, France (e-mail: kpalin@bordeaux.inra.fr). saccharide (LPS) in rat $(18,24,25)$ and sheep (36) and intense nuclear c-fos immunoreactivity in AVP containing magnocellular neurons of the rat $\operatorname{SON}(35,40)$ and PVN $(20,50)$.

The mechanisms that are responsible for the activation of AVP neurons in response to an endotoxin challenge need to be elucidated. Potentially, dysregulation in water homeostasis caused by LPS-induced fever and inflammation could be responsible for AVP neuron activation. However, endotoxininduced AVP activation occurs independently of changes in plasma osmolality, systemic blood pressure, and plasma volume (25). Furthermore, ablation of the lamina terminalis (consisting of the subfornical organ, organum vasculosum of the lamina terminalis, and median preoptic nucleus) that is critical in mediating osmotic sensitivity and associated AVP release does not prevent LPS-stimulated plasma AVP release in sheep (36). Thus, it appears that AVP neuron activation is not secondary to alteration of water balance. Besides, a direct action of LPS on hypothalamic magnocellular neurons appears unlikely, because endotoxin does not penetrate the blood-brain barrier (17).

Recent evidence suggests that inflammatory factors induced in hypothalamus by LPS treatment, such as prostaglandin- $\mathrm{E}_{2}$ $\left(\mathrm{PG}-\mathrm{E}_{2}\right)$, interleukin (IL)-1 $\beta$, IL-6, and tumor necrosis factor- $\alpha$ $(\mathrm{TNF} \alpha)(15)$, could contribute to the AVP neuron activation process $(29,34)$. PGs are able to enhance the secretion of AVP in sheep (4), likely by acting through several receptor types expressed in the PVN (53) and SON (47), such as EP3 and EP4 (44). IL-1 $\beta$ is also excitatory, as attested by the increase in AVP concentration in the portal blood of anesthetized rats (43) and in the plasma of conscious, freely moving rats (39) following intravenous (iv) injection of IL-1 $\beta$. This cytokine acts centrally since the intracerebroventricular (icv) IL-1 $\beta$ injection increases the content of AVP in blood microdialysates (29) and iv injection of IL-1 $\beta$ activates the AVP neurons mainly via ERK1/2 pathway (49). Additionnaly, IL-6 is expressed by astrocytes (40) and by AVP neurons $(16,20)$ in rat SON and PVN, an expression increased by LPS (40) or dehydration (16, 20). Furthermore, systemic injection of IL-6 stimulates plasma AVP release in humans (34). $\mathrm{TNF} \alpha$ is a potential candidate since $\mathrm{TNF} \alpha$ mRNA level is increased by IL- $1 \beta, \mathrm{TNF} \alpha$ also increases IL-1 $\beta$ mRNAs (6), and $\mathrm{TNF} \alpha$ is known to activate the hypothalamo-pituitary-adrenocortical axis (12).

The aim of this study was to elucidate those factors that underlie the activation of AVP neurons in response to immune stimulation as mimicked by an intraperitoneal (ip) injection of LPS in male Wistar rats. Although both PVN and SON neurons are known to be simultaneously activated by many stimuli, and 
in particular by LPS (50), the present study was focused on the SON, because this structure is more homogenous than the PVN, since it contains only magnocellular neurons. We have hypothesized that the inflammatory molecules such PG- $\mathrm{E}_{2}$, IL-1 $\beta$, IL-6, or TNF $\alpha$ could directly activate AVP neurons. In this work, we first confirmed the LPS induced-activation of AVP neurons by measuring the plasma AVP concentration, the diuresis, the expression of c-Fos, and the electrical in vivo activity of AVP neurons in the rat SON. Then, we assessed the relationship between this activation and possible changes in plasma osmolality, blood pressure, and mRNA expression of inflammatory molecules (PG-E $E_{2}, \mathrm{IL}-1 \beta$, IL-6, and TNF $\alpha$ ) in the SON. In vivo electrophysiological studies of AVP neuron activity were finally performed in SON with the recombinant and antibody molecules of the pertinent inflammatory candidate.

\section{METHODS}

\section{Animals}

Adult male Wistar rats (250-350 g; Janvier) were housed in an air-conditioned room at $22.5 \pm 0.5^{\circ} \mathrm{C}$ on a $12: 12$-h light-dark cycle (lights on at 8:00 AM) with food and water provided ad libitum. Each rat was handled twice/day for $5 \mathrm{~min}$ for 3 days to minimize stress of experimentation. To maintain the nycthemeral cycle of supraoptic c-Fos expression and AVP release, rats were always euthanized between 10:00 and 12:00 AM (see explanations in Ref. 40). All experiments were carried out in accordance with the European Communities Council Directive (November 24, 1986; 86/609/EEC), and measures were taken to minimize pain and discomfort. All experiments in our paper were approved by the Comité régional d'éthique Aquitaine et Poitou Charentes pour l'expérimentation animale. In addition, the Direction départementale des services vétérinaires de la Gironde gives us the authorization to perform experiments on live vertebrate animals.

\section{Treatments}

LPS. To induce inflammation, we used LPS (Escherichia coli, serotype 0127:B8; Sigma) diluted in phosphate-buffered saline (PBS; $0.1 \mathrm{M})$. The $\mathrm{pH}$ of phosphate buffer was adjusted to 7.4, and osmolality was $300 \pm 2 \mathrm{mOsm} / \mathrm{l}$ in endotoxin-free sterile water. For all experiments, LPS was injected ip at the concentration of $250 \mu \mathrm{g} / \mathrm{kg}$ body wt (27). PBS was used as the control for LPS injection.

IL-6. Recombinant rat IL-6 (R \& D Systems) was dissolved in artificial cerebrospinal fluid (aCSF; $\mathrm{NaHCO}_{3} 26.2 \mathrm{mM}$, glucose 10 $\mathrm{mM}, \mathrm{NaCl} 120 \mathrm{mM}, \mathrm{Na}_{2} \mathrm{HPO}_{4} 1 \mathrm{mM}, \mathrm{KCl} 2.5 \mathrm{mM}, \mathrm{MgCl}_{2} 1 \mathrm{mM}$, $\mathrm{CaCl}_{2} 2.5 \mathrm{mM}$ ) and injected in the third ventricle (icv) at the concentration $80 \mathrm{ng} / 2 \mu \mathrm{l}$.

Anti-IL-6 antibodies. The neutralizing goat anti-rat IL-6 antibodies (neutralizing mixture; R \& D Systems) were also dissolved in aCSF. Given the dissociation constant $\left(K_{\mathrm{d}}\right)$ of IL-6 for its receptor (100 $\mu \mathrm{g} / \mathrm{ml})$, we estimated that at least the $2 \times K_{\mathrm{d}}$ (200 ng/rat) concentrations of these neutralizing antibodies were needed to observe an effect. Thirty minutes prior to ip LPS injection, the anti-IL-6 antibodies were administered icv in $2 \mu l$ to nonanesthetized or anesthetized animals. Each rat received only one combination of treatments (aCSF and IL-6).

\section{Quantification of mRNA Levels in the SON}

The metabolic activation within SON cells was revealed by measuring (RT-PCR) the expression of $c$-fos mRNA and its product (8, 38) using a sensitive technique, the real-time PCR.

Adult rats were deeply anesthetized with pentobarbital sodium (Sagatal, Rhone Merieux, Harlow, Essex, UK) and transcardially perfused with heparinized phosphate-buffered saline, pH 7.4 (Trevi- gen). Both SON were rapidly microdissected and frozen in liquid nitrogen. Total RNA was extracted using Qiagen RNeasy microcolumns, and contaminating DNA was degraded with Qiagen RNase-free DNase 1 according to the manufacturer's instructions (Qiagen). Yields were determined spectrophotometrically at $260 \mathrm{~nm}$. For reverse transcription, all reagents were provided by Invitrogen except for RNasin, which was purchased from Promega. Complementary DNA (cDNA) synthesis was carried out in a $20-\mu l$ reaction final volume containing $200 \mathrm{ng}$ of total mRNA, $1 \mu \mathrm{l}$ of $10 \mathrm{mM}$ dNTP mix (10 mM each dATP, dGTP, dCTP, and dTTP at neutral $\mathrm{pH}$ ), and $1 \mu \mathrm{l}$ of random hexamers $(100 \mathrm{ng} / \mu \mathrm{l})$ and in RNase free water. After $5 \mathrm{~min}$ of incubation at $65^{\circ} \mathrm{C}$, samples were mixed and quickly chilled on ice. Four microliters of $5 \times$ first-strand buffer, $2 \mu 1$ of $0.1 \mathrm{M}$ DTT, and 0.5 $\mu l$ of RNasin were then added, followed by incubation at $37^{\circ} \mathrm{C}$ for 2 min. Finally, $1 \mu \mathrm{l}$ (200 units) of Moloney murine leukemia virus retrotranscriptase was added followed by incubation at $25^{\circ} \mathrm{C}$ for 10 min and then at $37^{\circ} \mathrm{C}$ for $50 \mathrm{~min}$ and inactivation by heating at $70^{\circ} \mathrm{C}$ for $15 \mathrm{~min}$.

Real-time SYBR Green polymerase chain reaction. PCR primers were designed using Primer Express 1.0 software according to published sequences for rat (Sigma-Genosys). All primers designed and used in these experiments are summarized in Table 1. Additionally, probes were designed to span an intron-exon boundary to be specific for cDNA and did not amplify genomic DNA. SYBR Green PCR was carried out in a $10-\mu$ l reaction final volume with $1 \mu$ l (equivalent to $10 \mathrm{ng}$ of RNA input) of cDNA template, $1 \mu \mathrm{l}$ of each reverse and forward primer $(0.3 \mu \mathrm{M})$, and $5 \times$ SYBR Green PCR Master Mix (Applied Biosystems). Cycling conditions were $50^{\circ} \mathrm{C}$ for $2 \mathrm{~min}$ and $95^{\circ} \mathrm{C}$ for $10 \mathrm{~min}$, followed by a 40 -cycle amplification phase of $95^{\circ} \mathrm{C}$ for $15 \mathrm{~s}$ and $60^{\circ} \mathrm{C}$ for $1 \mathrm{~min}$ on the Applied Biosystems PRISM 7000 sequence detection system. Samples were assayed in duplicate and quantified by generating a standard curve, as described below.

$m R N A$ quantification analysis. A standard curve was constructed from total RNA, which was isolated from the SON of $3 \mathrm{~h}$ post-LPStreated rats $(n=3)$. This challenge induces brain transcription of the genes that were evaluated in these experiments (42). Total RNA was extracted from this tissue, and cDNA was synthesized using $2 \mu \mathrm{g}$ RNA in a 50- $\mu$ l reaction volume using the reverse transcription reagents as described above. A dilution series (1/5, 1/25, 1/125, 1/625, $1 / 3,125)$ of this cDNA product was then used for each SYBR green PCR to generate a standard curve of the gene expression. The amount of each specific gene and GAPDH mRNA expression was quantified relative to the target mRNA level extracted from the total mRNA of the SON from 3-h ip LPS-stimulated rats. Results are expressed as the ratio of specific mRNA normalized to the housekeeping gene GAPDH.

Table 1. Rat SYBR Green primer probe sequences used in this paper

\begin{tabular}{ll}
\hline \hline Target Gene (Accession No.) & \multicolumn{1}{c}{ Primer $\left(5^{\prime}-3^{\prime}\right)$} \\
\hline GAPDH (24383) & \\
$\quad$ Forward & \\
Reverse & AACTCCCTCAAGATTGTCAGCAA \\
c-fos $(314322)$ & GGCTAAGCAGTTGGTGGTGC \\
$\quad$ Forward & GTCAACACACAGGACTTTTGCG \\
Reverse & CGTGGGGATAAAGTGGCACT \\
IL-6 $(24498)$ & \\
$\quad$ Forward & TGAGAAAAGAGTTGTGCAATGG \\
Reverse & GCATCATCGCTGTTCATACAAT \\
TNF $\alpha(24835)$ & \\
$\quad$ Forward & TGGGCTCCCTCTCATCAGTT \\
Reverse & AGAAGATGATCTGAGTGTGAGG \\
IL-1 $\beta(24494)$ & \\
Forward & CCTGAACTCAACTGTGAAATAGCAG \\
Reverse & CAGGTCATTCTCCTCACTGTCG \\
\hline
\end{tabular}




\section{Immunohistochemistry in SON}

Control handled rats $(n=3)$ or rats treated with LPS and euthanized 1 or $2 \mathrm{~h}$ afterward $(n=3)$ were terminally anesthetized with pentobarbital sodium (Sagatal, Rhone Merieux, Harlow, Essex, UK). They were then fixed by an intracardiac perfusion with PBS, pH 7.4, followed by $250 \mathrm{ml}$ of fixative, including $4 \%$ paraformaldehyde in PBS, pH 7.4. After dissection, the brains were immersed for $24 \mathrm{~h}$ in the fixative and then cut frontally into $50-\mu \mathrm{m}$ thick sections with a vibratome (VT1000S; Leica, Rueil Malmaison, France). All floating sections were first saturated for $1 \mathrm{~h}$ at room temperature in PBS containing $4 \%$ bovine serum albumin and $0.1 \%$ Triton $\mathrm{X}-100$. The floating sections were then carefully rinsed in PBS. For c-Fos-AVP double staining, free-floating sections were incubated overnight at room temperature with the two primary antibodies simultaneously, diluted in $3 \%$ bovine serum albumin/0.3\% Triton X-100. Dilution factor was 1:1,000 for anti-c-Fos antibody (rabbit anti-c-Fos reactive for c-Fos p32; Santa Cruz Biotechnology, Santa Cruz, CA) and 1:2,000 for guinea pig anti-AVP (Arg-8) antibody (Peninsula Laboratories). After being rinsed, sections were incubated with secondary antibodies diluted in PBS containing 3\% bovine serum albumin for $2 \mathrm{~h}$ at room temperature. An anti-rabbit Alexa 488-conjugated secondary antibody (1:200; Interchim) was used for c-Fos immunostaining. AVP was revealed by a biotinylated goat anti-guinea pig antibody (1:4,000; Vector Laboratories) and then visualized using a streptavidin Alexa 594 (1:4,000) in PBS (Molecular Probes).

For IL-6/glial fibrillary acidic protein (GFAP) double staining, free-floating sections were incubated overnight at room temperature with goat anti-IL-6 antibody diluted at 1:500 in PBS containing 0.2\% bovine serum albumin and $0.1 \%$ Triton $\mathrm{X}-100$. After being rinsed, sections were incubated overnight at room temperature with a rabbit anti-GFAP antibody (Dako, Glostrup, Denmark) diluted at 1:1,000 in PBS containing $1 \%$ bovine serum albumin and $0.3 \%$ Triton $\mathrm{X}-100$. To reveal GFAP immunoreactivity, sections were incubated for $2 \mathrm{~h}$ at room temperature with anti-rabbit secondary antibody Alexa 594 (1:2,000 in PBS-1\% BSA-0.3\% Triton X-100; Molecular Probes). Simultaneously, sections were incubated with a biotinylated anti-goat antibody (1:200 in PBS- $0.2 \%$ BSA-0.1\% Triton X-100, $2 \mathrm{~h}$ at room temperature; Amersham Biosciences) to reveal IL- 6 and then visualized using streptavidin Alexa 488 (1:200 in PBS, 2 h at room temperature; Molecular Probes). A Leica SP2 confocal laser (Ar/He/Ne) scanning microscope (Heidelberg, Germany) was used to visualize the fluorescent signal associated with each antibody. To avoid overlapping and false positive signals, each fluorescent signal was still scanned independently, and all scanning parameters were strictly conserved.

\section{Measurement of Plasma AVP Concentration and Measurement of Osmolality}

Plasma AVP release was quantified in control handled ( $n=4 /$ time posttreatment), PBS-treated ( $n=4 /$ time posttreatment), and LPStreated rats $(n=63)$ killed at $1,2,3,6$, and $18 \mathrm{~h}$ posttreatment (for LPS, $n$ is equal to $20,19,8,8$, and 8 , respectively according to time groups). All rats were decapitated to collect blood in chilled tubes coated with heparin (CML, Nemours, France). Blood was centrifuged at $1,600 \mathrm{~g}$ for $15 \mathrm{~min}$ at $4^{\circ} \mathrm{C}$. Plasma samples were then analyzed for AVP levels and osmolality.

AVP was extracted from the plasma by adding an equal volume of $1 \%$ trifluoroacetic acid (TFA) to the sample and centrifuged at 17,000 $g$ for $15 \mathrm{~min}$ at $4{ }^{\circ} \mathrm{C}$. Removed supernates were applied on a 200-mg C18 column previously equilibrated with $1 \mathrm{ml}$ of acetonitrile and 25 $\mathrm{ml}$ of $1 \%$ TFA. After being washed with $20 \mathrm{ml}$ of $1 \%$ TFA, samples were slowly eluted in a glass tube by applying $3 \mathrm{ml}$ of a 60:40 solution of acetonitrile, 1\% TFA to the column. Finally, samples were evaporated until dry using a centrifugal concentrator under vacuum and stored at $-80^{\circ} \mathrm{C}$ until use. Plasma AVP levels were measured in duplicate using a specific, nonradioactive, and competitive binding AVP assay (R \& D Systems Europe) as described by the manufacturer's instructions. The sensitivity of this assay was $<3.4$ $\mathrm{pg} / \mathrm{ml}$ [intra-assay precision, confidence factor $(\mathrm{CF})=8.0 \%$; and inter-assay precision, $\mathrm{CF}=7.4 \%$ ].

Plasma osmolality was measured by freezing point depression with an automatic Roebling type 13 Autocal Micro-Osmometer (Avantec) in all plasma samples used to measure AVP concentration.

\section{Quantification of $P G-E_{2}$ in $S O N$}

Handled 30-min and 1-, 3-, and 6-h post-LPS-treated rats $(n=$ 5/group) were terminally anesthetized with pentobarbital sodium (Sagatal, Rhone Merieux, Harlow, Essex, UK), perfused via the carotid artery with heparinized PBS, and then decapitated. Both SON were rapidly microdissected and frozen in liquid nitrogen. Briefly, brain extracts were homogenized in the presence of a protease inhibitor cocktail (Sigma, St. Quentin Fallavier, France) and centrifuged for $10 \mathrm{~min}$ at $12,000 \mathrm{~g}$ to remove nuclei, and organelles were then stored at $-80^{\circ} \mathrm{C}$ before use. Using a $\mathrm{PG}-\mathrm{E}_{2}$ EIA kit monoclonal, quantification of $\mathrm{PG}-\mathrm{E}_{2}$ in SON was performed as described by the manufacturer (Cayman Chemical, Ann Arbor, MI). The sensitivity threshold of this assay was $7.8 \mathrm{pg} / \mathrm{ml}$ (intra-assay precision, $\mathrm{CF}=3.8 \%$; and interassay precision, $\mathrm{CF}=9.4 \%$ ). The bicinchoninic acid method (Interchim, Montluçon, France), using albumin as standard, determined total protein content in SON (45).

\section{Measures of Metabolic Parameters}

Animals were housed individually in metabolic cages for 3 days prior to initiation of before treatments and managed by the same person. Rats were injected ip with PBS or LPS at 9:00 AM. Each rat served as its own control, and cumulative urine flow was measured every $2 \mathrm{~h}$ from 0900 to 1800 . Water intake $(\mathrm{ml})$, body weight $(\mathrm{g})$, and food intake $(\mathrm{g})$ were measured $24 \mathrm{~h}$ after treatment.

\section{In Vivo Electrophysiological Recordings}

Preparation of animals. Experiments were performed on male Wistar rats (300-350 g body wt) that were anesthetized with urethane (ethyl carbamate, $1.25 \mathrm{~g} / \mathrm{kg}$ ip injected; Sigma) and placed in a stereotaxic frame at an ambient temperature of $28.5 \pm 0.5^{\circ} \mathrm{C}$. After trepanning, a bipolar stimulating electrode was inserted into the pituitary stalk at the limit of the neurohypophysis according to a stereotaxic atlas (1) [anteriority $(\mathrm{A})=4.7$, laterality $(\mathrm{L})=0$, height $(\mathrm{H})=0.5]$ for antidromic identification of magnocellular neurons from SON. The exact position of the electrode was attested by a posteriori observation of the site of lesion provoked by electrical current (10 mA during a few seconds). Recording glass micropipettes filled with $0.5 \mathrm{M}$ sodium acetate solution (8-20 M $\Omega$ impedance) were placed in the SON $(\mathrm{A}=7-8, \mathrm{~L}=1-2.3, \mathrm{H}=2-2.5)$ and connected to conventional electrophysiological apparatus. Extracellular electrical activities were displayed on a chart recorder (Astromed, Trappes, France) and simultaneously stored on a computer by means of a Cambridge Electronic Design (Cambridge, UK) 1401 interface card.

Continuous measurement of arterial blood pressure. Mean arterial blood pressure was continuously monitored by inserting a polyethylene catheter (filled with $100 \mathrm{U} / \mathrm{ml}$ heparinized saline solution) into the left femoral artery attached to a transducer (model TDX-300; Micro-Med) that was connected to a blood pressure analyzer (model BPA-400a; Micro-Med) and simultaneously stored on a computer by means of a Cambridge Electronic Design 1401 interface card. Blood pressure was recorded in anesthetized animals before and $\leq 4 \mathrm{~h}$ after LPS injection. Control values were taken for $1 \mathrm{~h}$ before the injection of PBS or LPS.

Identification of neurons and data analysis. The magnocellular neurons were identified by their antidromic response to electrical stimulation of the neurohypophysis (the response had constant latency, followed high frequency stimulation, and collided with an orthodromic spike). Because phasic activity is a major characteristic of AVP neurons (for review, see Ref. 2), presumed AVP neurons were in 
most cases characterized by their phasic activity comprising distinct periods of activity separated by periods of silence (see example in Fig. 2).

Electrophysiological data analysis. Analysis of the electrophysiological recordings was performed using both in-house programs and Spike2 analysis software (Cambridge Electronic Design). The phasic pattern of AVP neurons was characterized by the following parameters: $F$, the mean frequency of spikes (in spikes/s) during each period of analysis; $f$, the intraburst frequency (in spikes/s), i.e., the mean firing rate during periods of activity; and $Q$, the proportion of time spent by a phasic cell in active periods (calculated by exclusion of silent periods superior to $2 \mathrm{~s}$ ). This last parameter is equivalent to the activity quotient described previously (48). All parameters were calculated for periods of $\sim 600 \mathrm{~s}$.

Experimental design and statistical analyses. All experiments were arranged as completely randomized designs. Data were analyzed by ANOVA, and post hoc comparisons of individual group means were carried out by the protected least significant difference test. All results were summarized and presented as means \pm SE. Measures were taken to minimize the number of animals. We verified that mRNA levels and plasma AVP concentrations from handled and 1-h post-PBSinjected rats never differed.

\section{RESULTS}

\section{Rapid and Sustained Activation of AVP Neurons During Immune Challenge}

To assess activation of SON neurons, we measured the expression of $c$-fos proto-oncogene mRNA and its product (8, 38). Compared with control, LPS treatment significantly increased the expression of $c$-fos mRNA in SON [ANOVA: $F(6,14)=15.0, P<0.001$; Fig. $1 A]$. Student-Newman-Keuls post hoc test assessed that $c$-fos mRNA peak expression occurred $30 \mathrm{~min}$ post-LPS treatment, and, although it declined with time, the increase was still significant $\leq 6 \mathrm{~h}$ post-LPS. Consistent with this result, numerous AVP neurons of the SON showed Fos-stained cell nuclei as early as $1 \mathrm{~h}$ post-LPS injection (Fig. 2).

To confirm the rapid and sustained activation of AVP neurons in response to LPS challenge, plasma concentration of AVP ([AVP]) was measured in handled, PBS-treated, and LPS-treated rats (Fig. 1B). Compared with control groups, plasma [AVP] significantly increased after LPS administration [ANOVA: $F(2,88)=15.7, P<0.0001]$. The plasma [AVP] increase was significant between 1 and $6 \mathrm{~h}$ post-LPS, with a maximal release at 3 and $6 \mathrm{~h}$.

Functional significance of AVP release was verified by measuring cumulative diuresis in handled, PBS-treated, and LPStreated rats ( $n=10$ /group) at 2 -h intervals for $8 \mathrm{~h}$ (Fig. 1C). As expected, LPS treatment was associated with a significant decrease of urine volume flow compared with handling and PBS treatment [repeated-measures ANOVA: $F(2,40)=9.8, P<$ $0.001]$. There was no significant difference between handling and PBS treatment. Post hoc test confirmed that cumulative urine flow was significantly decreased between 0 and $6 \mathrm{~h}$ post-LPS and returned toward baseline value thereafter.

\section{Peripheral Immune Challenge Induces an Early Increase in AVP Neuron Electrical Activity}

Because LPS injection has been shown to induce an increase of plasma AVP concentration in adult rats $(18,25)$, we studied the evolution of the electrical activity of AVP neurons in response to a LPS peripheral injection in anesthetized adult rats. Only AVP neurons initially displaying a phasic activity were considered.
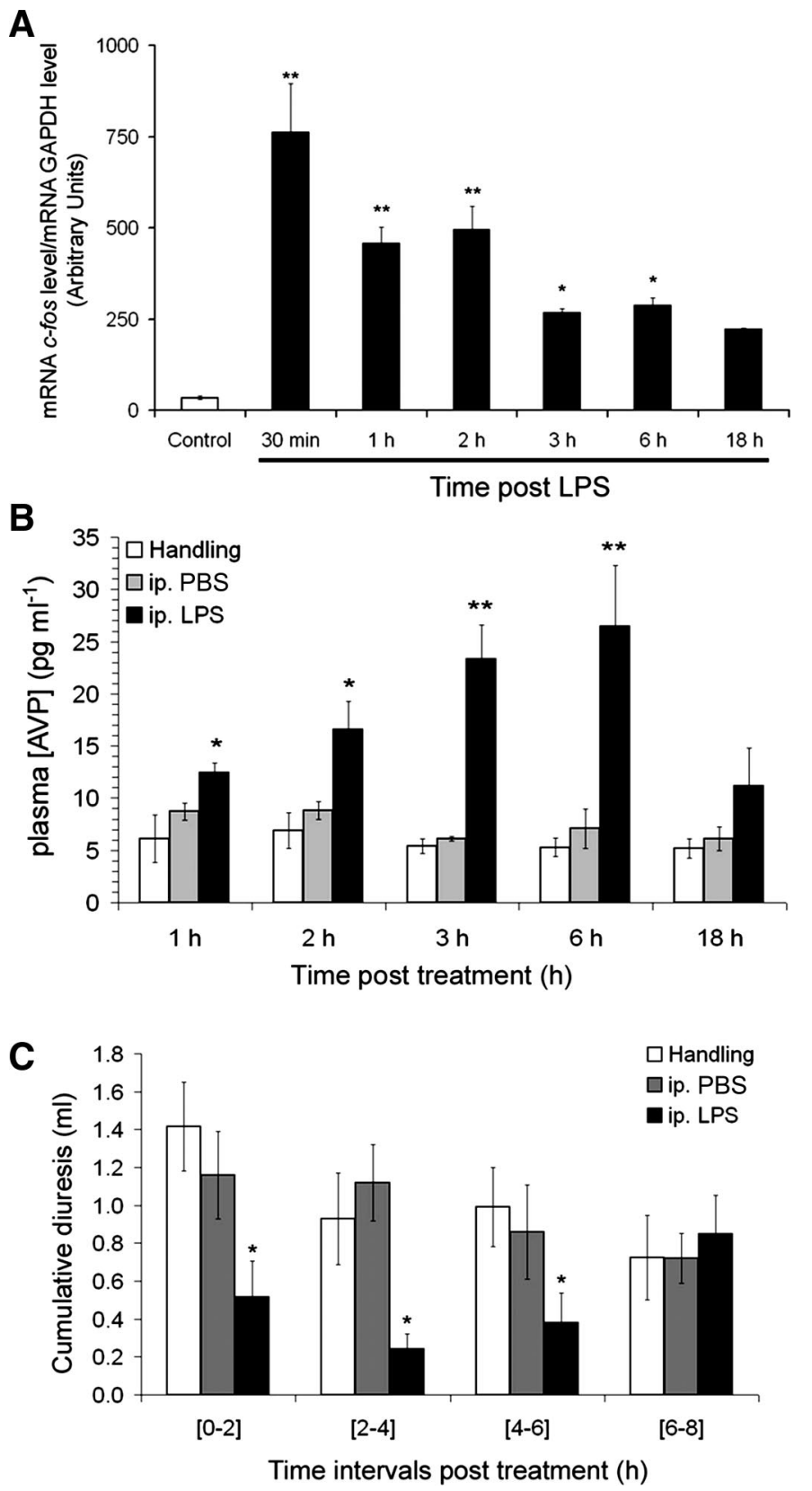

Fig. 1. Rapid and sustained activation of arginine vasopressin (AVP) neurons in supraoptic nucleus (SON) after lipopolysaccharide (LPS) treatment. A: using real-time PCR, mRNA $c$-fos level was quantified and normalized to mRNA GAPDH level (arbitrary units) in control (1 h post-PBS injection) and in LPS-treated rats at different times postinjection $(30 \mathrm{~min}, 1 \mathrm{~h}, 2 \mathrm{~h}, 3 \mathrm{~h}, 6 \mathrm{~h}$, and 18 h) ( $n=3 /$ group). Compared with control, LPS treatment increased mRNA $c$-fos level with time (ANOVA followed by Student-Newman-Keuls post hoc test: $* P<0.05$ and $* * P<0.01)$. $B$ : using specific competitive binding assay, AVP concentration $(\mathrm{pg} / \mathrm{ml})$ was measured in plasma of handled, PBS-treated, and LPS-treated rats at different times posttreatment (1, 2, 3, 6, and $18 \mathrm{~h}$ ) (see METHODS for $n$ /group). Compared with handling and PBS treatment, LPS injection increased plasma AVP release with time (ANOVA followed by Student-Newman-Keuls post hoc test: $* P<0.05$ and $* * P<0.01)$. $C$ : cumulative urine flow (diuresis, $\mathrm{ml}$ ) was measured in handled, PBS-treated, and LPS-treated rats every 2-h period after treatment between 1000 and 1800 . Animals were individually housed in a metabolic cage, and each one was its own handled and PBS-treated control $(n=10$ /group). Compared with handling and PBS treatment, LPS injection decreased urine flow volume with time (ANOVA followed by Student-Newman-Keuls post hoc test: $* P<0.05$ ). ip, Intraperitoneal. 
Saline
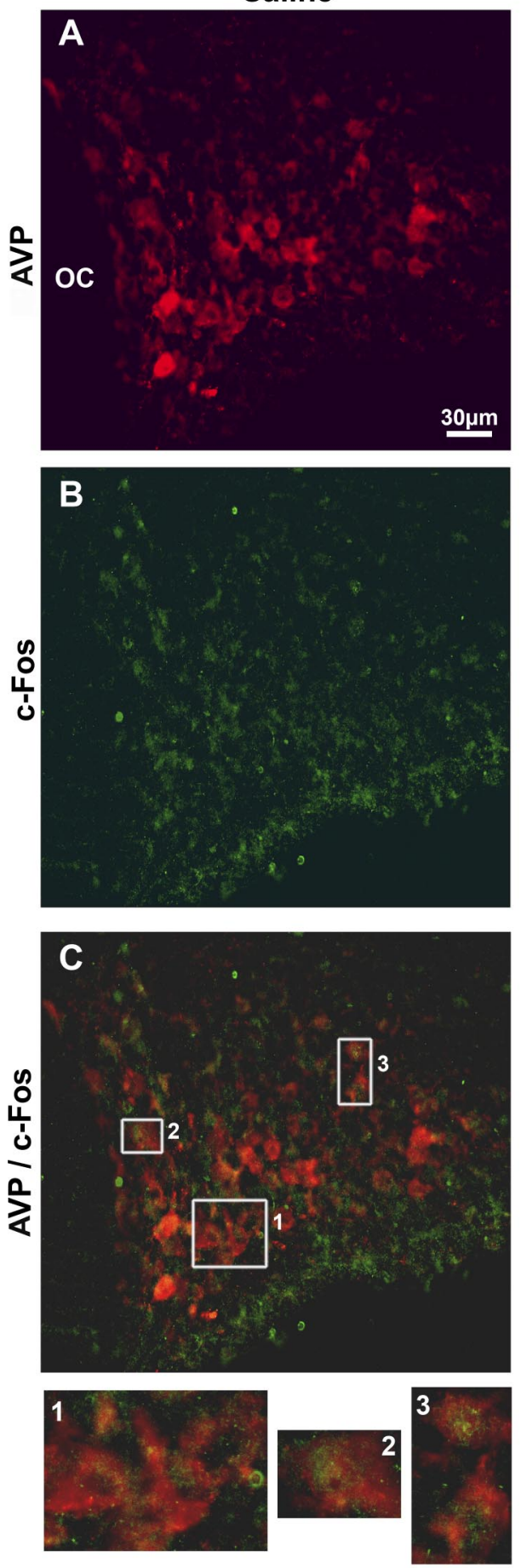
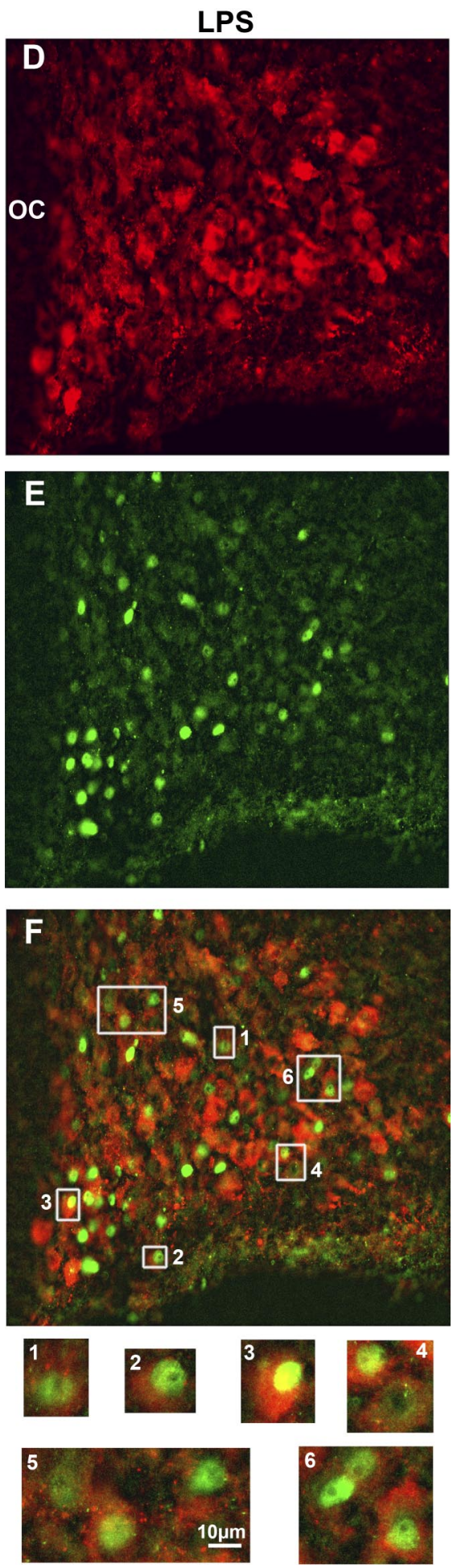

Fig. 2. Expression of c-Fos in AVP neurons of the SON $1 \mathrm{~h}$ post-LPS injection. $A$ and $D$ : immunohistochemistry of AVP in control and LPS-treated rats. $B$ and $E$ : immunohistochemistry of c-Fos in control and LPS-treated rats. $C$ and $F$ : merge of $A$ and $B$ and $D$ and $E$ showing colocalization of Fos positive nuclei in AVP positive neurons (scale bar $=30 \mu \mathrm{m}$ ). Compared with control, Fos protein expression was dramatically increased $1 \mathrm{~h}$ post-LPS treatment $(n=$ 3/group) and expressed in numerous labeled AVP neurons. Boxed areas in $C$ and $F$ are numbered and enlarged below with scale bars. OC, optic chiasma; AVP, arginine vasopressin.
LPS injection induced a progressive activation of all AVP neurons $(n=8)$. Activation consisted mainly of an increase in the duration of the active periods and/or a decrease in the duration of the silent periods (Fig. 3A). This effect was translated by an increase in both the mean frequency, $F$, and in the activity quotient, $Q$ (Fig. 2B). No change was displayed for the intraburst frequency, $f$. Activation was particularly strong $1 \mathrm{~h}$ after treatment, as attested by the significant increase in $F$ [repeated- measures ANOVA: $F(1,7)=29.464, P<0.01$ ] and $Q$ [repeatedmeasures ANOVA: $F(1,7)=29.008, P<0.05$ ] (Fig. 3).

\section{Immune Challenge Does Not Change Plasma Osmolality but} Induces a Transient Blood Pressure Increase

Plasma osmolality and blood pressure were measured in LPS-treated rats to determine whether the LPS-induced acti- 


\section{A}

Fig. 3. AVP neuron electrical activity increases after LPS treatment. Adult rats were anesthetized, and AVP neuron electrical activity was recorded by electrophysiology in SON. A: discontinuous recordings showing the evolution of the electrical activity of an AVP neuron recorded before (control) and $1 \mathrm{~h}$ after the LPS peripheral injection. Frequency $(F)$ is expressed in spikes/s. $B$ : histograms represent the averaged values of the frequency of discharge, $F$, and the activity quotient $(Q)$ for 8 neurons (repeated-measures ANOVA: $* P<0,05)$. Each neuron was its own control.
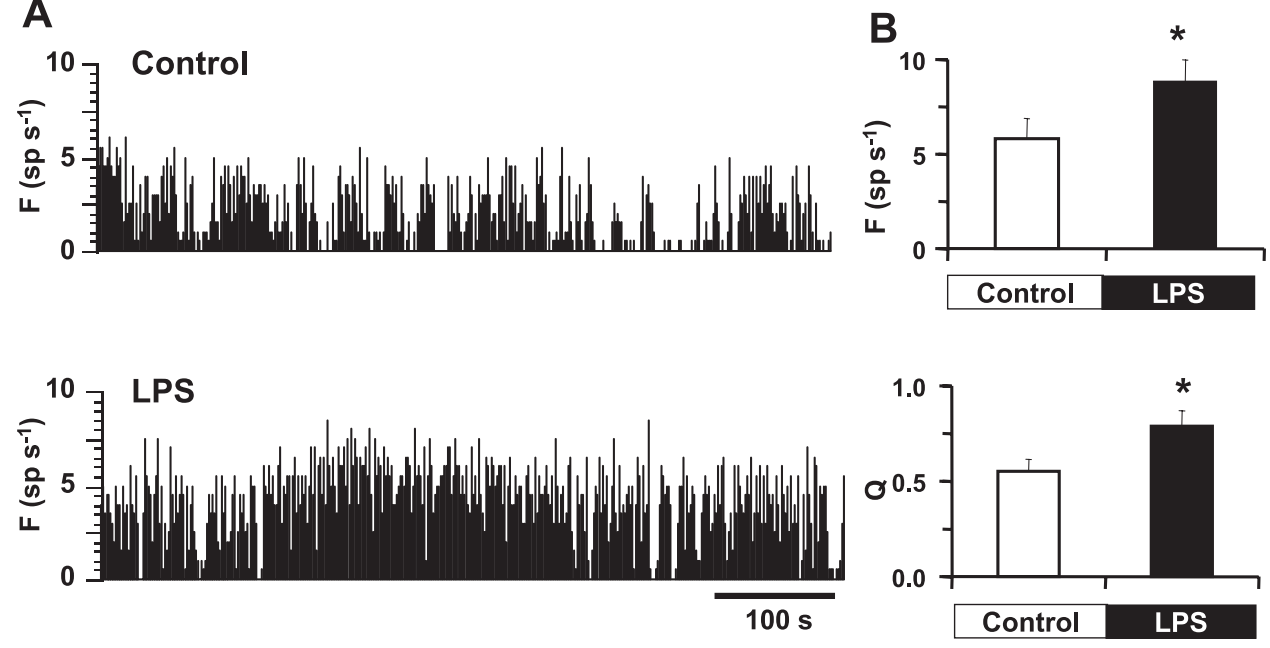

vation of AVP neurons could depend on possible variation of these parameters (Fig. 4). Plasma osmolality did not change with time after LPS injection compared with control and PBS treatment (Fig. 4A). Mean arterial blood pressure measured in the femoral artery transiently increased between 10 and $80 \mathrm{~min}$ after LPS injection and then returned to basal levels [repeatedmeasures ANOVA, treatment $\times$ time: $F(1,21)=65.8, P<$
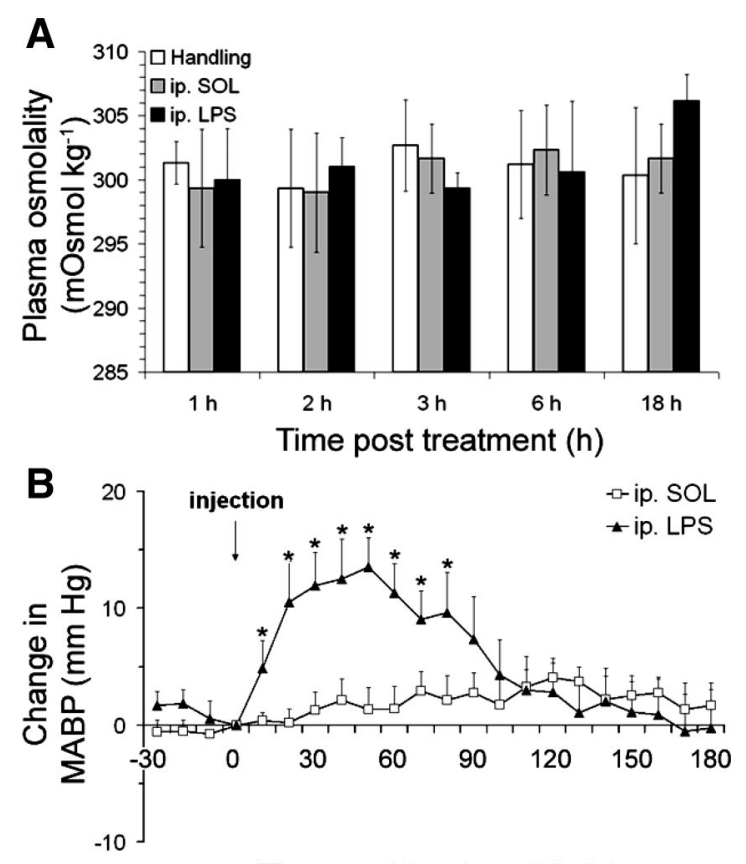

Time post treatment (min)

Fig. 4. Plasma osmolality and arterial blood pressure variations after LPS treatment. $A$ : using an automatic micro-osmometer, plasma osmolality $(\mathrm{mOsmol} / \mathrm{kg}$ ) was measured in blood samples of handled, PBS-treated, and LPS-treated rats at different times posttreatment $(1,2,3,6$, and $18 \mathrm{~h}$ ) previously used to measure AVP concentration ([AVP]). No difference was observed between treatments and time. $B$ : mean arterial blood pressure (MABP; $\mathrm{mmHg}$ ) was measured continuously in femoral artery in anesthetized rats for $\leq 3 \mathrm{~h}$ after PBS $(n=5)$ and LPS injection $(n=6)$. Compared with PBS treatment, LPS injection increased MABP between 10 and $80 \mathrm{~min}$ (repeated-measures ANOVA followed by Student-Newman-Keuls post hoc test: $* P<0.05)$.
0.05; Fig. 4B], whereas activation of AVP neurons carried on. Blood pressure was unchanged after PBS injection.

\section{Immune Challenge Induces a Delayed Increase in $P G-E_{2}$ Concentration in the SON}

Because LPS-induced activation of AVP neurons could potentially result from a direct action of PG-E 2 (47), which could be released into the SON in response to immune challenge (28), we quantified PG-E $\mathrm{E}_{2}$ production in the SON after LPS treatment (Fig. 5). Compared with the control group, PG-E 2 concentration significantly increased in SON after LPS administration [ANOVA: $F(4,20)=3.8, P<0.05$ ]. However, this increase was only significant between 3 and $6 \mathrm{~h}$ post-LPS and not at earlier times (30 min and $1 \mathrm{~h}$ post-LPS injection).

Immune Challenge Induces an Early Increase in the IL-6 $m R N A$ Expression As Well As a Later Increase in the IL-1 $\beta$ and TNF $\alpha$ mRNA Expression in the SON

LPS peripheral injection is known to induce the increase in the expression of IL- $1 \beta$, IL- 6 , and $\mathrm{TNF} \alpha$ mRNA in pituitary and hypothalamus in rodents $1 \mathrm{~h}$ after injection $(15,31)$. On the

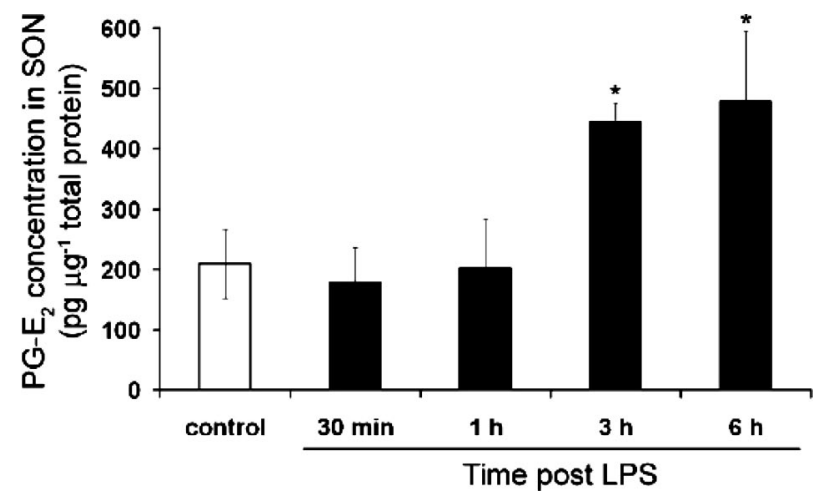

Fig. 5. Immune challenge induced a $\mathrm{PG}-\mathrm{E}_{2}$ concentration increase in $\mathrm{SON}$ Prostaglandin- $\mathrm{E}_{2}\left(\mathrm{PG}_{2} \mathrm{E}_{2}\right)$ concentration was quantified in SON and normalized to total quantity of SON proteins $(\mathrm{pg} / \mu \mathrm{g}$ total protein) in control $(1 \mathrm{~h}$ post-PBS injection) and LPS-treated rats at different times postinjection (30 min, $1 \mathrm{~h}, 3 \mathrm{~h}$, and $6 \mathrm{~h}$ ) ( $n=5$ /group). Compared with control, PG-E 2 level increased at 3 and $6 \mathrm{~h}$ in LPS-treated rats (ANOVA followed by StudentNewman-Keuls post hoc test: $* P<0.05$ ). 
other hand, IL-1 $\beta$ and IL-6 induced AVP release $(29,34,39)$, and IL- $1 \beta$ stimulated the activity of AVP neurons (33). Thus, we studied the effect of LPS peripheral injection on the mRNA expression of these three cytokines in the SON of adult rats treated with PBS (control rats) and $30 \mathrm{~min}, 1 \mathrm{~h}, 2 \mathrm{~h}, 3 \mathrm{~h}, 6 \mathrm{~h}$, and $18 \mathrm{~h}$ after an ip injection of LPS (Fig. 6).

In the SON, the expression of IL-1 $\beta$ mRNA was significantly increased $3 \mathrm{~h}$ after LPS treatment ( $n=3 /$ group) compared with the control rats $[F(6,15)=4.457, P<0.01]$. There was no significant difference in the expression of IL- $1 \beta$ mRNA $30 \mathrm{~min}, 1 \mathrm{~h}, 2 \mathrm{~h}, 6 \mathrm{~h}$, and $18 \mathrm{~h}$ after the LPS treatment compared with the PBS treatment. The same observations
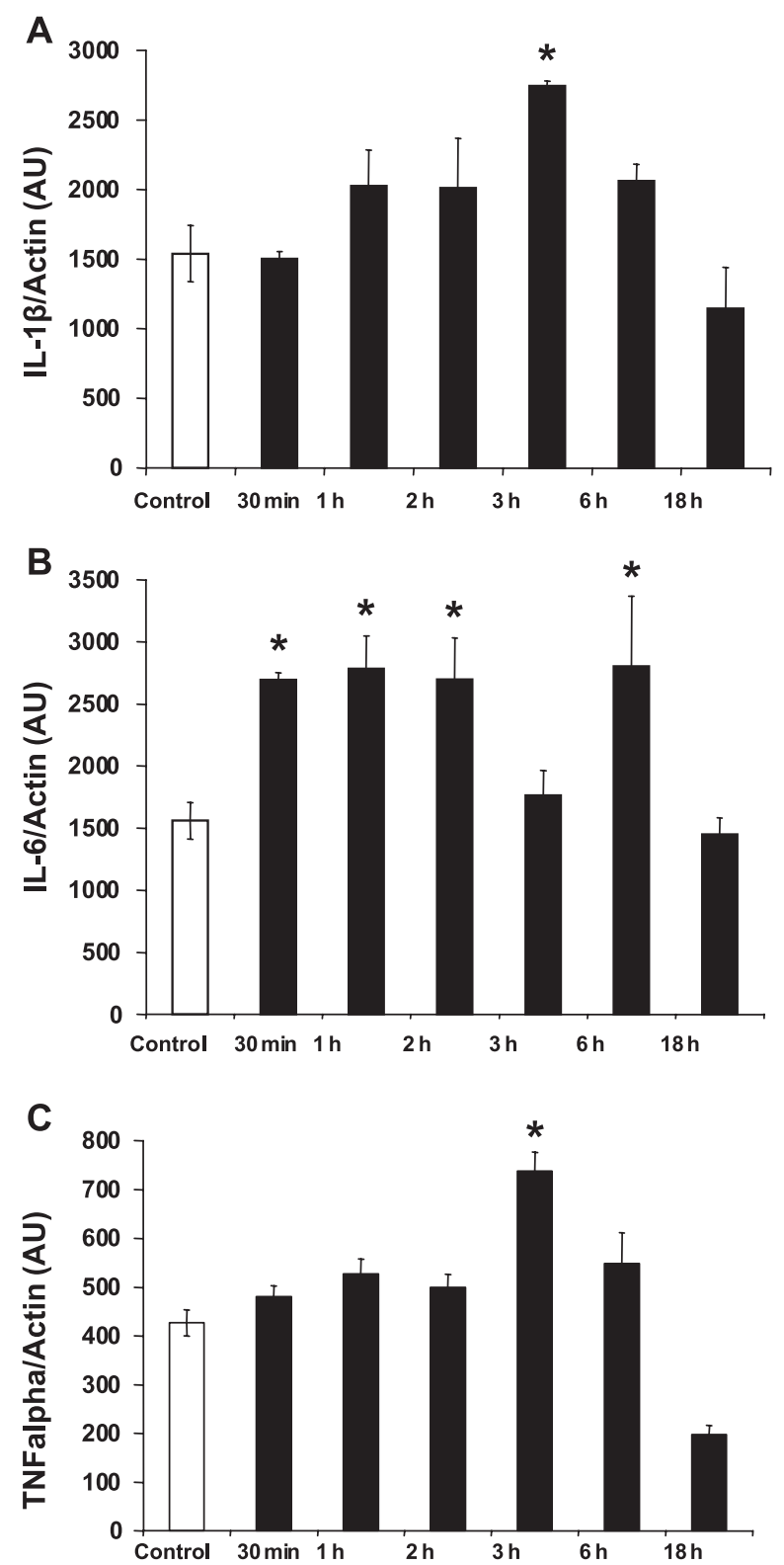

Fig. 6. Immune challenge induced an early increase in the IL-6 mRNA expression as well as a later increase in the IL-1 $\beta$ and TNF $\alpha$ mRNA expression in the SON. IL-1 $\beta(A)$, IL-6 $(B)$, and TNF $\alpha(C)$ mRNA were quantified by real-time RT-PCR and normalized to GAPDH mRNA [arbitrary units (AU)] in SON in control (PBS-treated rats) and LPS-treated rats at different times post-ip LPS injection ( $30 \mathrm{~min}, 1 \mathrm{~h}, 2 \mathrm{~h}, 3 \mathrm{~h}, 6 \mathrm{~h}$, and $18 \mathrm{~h})(n=$ 3/group, ANOVA: $* P<0.05$ ) apply for the expression of TNF $\alpha$ mRNA, which significantly increased only $3 \mathrm{~h}$ postinjection ( $n=3$ /group) $[F(6,14)=$ 24.14, $P<0.001]$. On the reverse, the expression of IL-6 mRNA increased significantly as early as $30 \mathrm{~min}$ after the LPS treatment compared with PBS injection $(n=3$ /group $)$ $[F(6,14)=5.35, P<0.01]$. This increase was maintained, being still significant 1, 2, and $6 \mathrm{~h}$ after LPS treatment. On the other hand, there was no significant difference in the expression of IL-6 mRNA 3 and $18 \mathrm{~h}$ after the treatment.

The stimulation of IL-6 expression in the SON of adult rats $2 \mathrm{~h}$ after LPS injection was confirmed by immunohistochemistry (Fig. 7).

\section{Central IL-6 Neutralizing Antibodies Prevents the LPS-Induced Activation of AVP Neurons}

We first tested the effect of icv injection of IL-6 neutralizing antibodies alone ( $\leq 60 \mathrm{~min})$ before applying LPS ip (250 $\mu \mathrm{g} / \mathrm{kg}$ ). The IL-6 neutralizing antibodies (200 ng/rat) were tested on six AVP neurons displaying a phasic pattern. The phasic pattern was inhibited by the IL- 6 antibodies, as attested by the decrease in $F$ [repeated-measures ANOVA: $F(1,5)=$ 7.78, $P<0.05$ ] and $Q$ [repeated-measures ANOVA, $F(1,5)=$ 75.07, $P<0.001]$ characterizing the phasic pattern (Fig. 8). The decrease in $f$ was not significant. When injected $40 \mathrm{~min}$ later, LPS did not induce activation in any neurons (Fig. 8).

\section{Central IL-6 Induces an Early Increase in the Electrical Activity of AVP Neurons}

We studied the effect of IL-6 icv injection ( $80 \mathrm{ng} / \mathrm{rat})$ on AVP neuron activity initially displaying a clear phasic pattern ( $n=5$ neurons) (Fig. 9). IL-6 induced a progressive activation of all neurons, consisting mainly of an increase in the duration of the active periods and/or a decrease in the duration of silences. These effects were translated by an increase in $F$ [repeated-measures ANOVA $F(1,4)=9.22, P<0.05$ ] and $Q$ [repeated-measures ANOVA $F(1,4)=35.49, P<0.05$ ], and these changes were highly significant $40 \mathrm{~min}$ postinjection, with each neuron being its own control. The change in the mean intraburst frequency, $f$, was not significant.

\section{DISCUSSION}

We investigated which changes in physiological parameter (plasma osmolality, blood pressure) or inflammatory brain factors (IL-1 $\beta$, IL-6, TNF $\alpha$, and PG- $\mathrm{E}_{2}$ ) could be correlated to and responsible for the activation of AVP neurons in response to an immune challenge (peripheral LPS injection). Using in vivo electrophysiological recordings, we emphasized the role of IL-6 in the early activation of AVP neurons. Indeed, central injection of IL-6 induced a progressive activation of AVP neurons that lasted $1 \mathrm{~h}$ and was similar in intensity and kinetics to that obtained after ip LPS injection. Prior treatment with anti-IL-6 antibodies decreased the basal phasic activity and prevented the LPS-induced activation of AVP neurons. These data suggest that IL-6 is a pertinent candidate underlying the onset of activation of AVP neurons during an immune challenge.

\section{AVP Neurons are Rapidly Activated by Peripheral LPS Injection}

Stimulation of $c$-fos mRNA in SON occurs as soon as 30 min after LPS and was maintained for $\leq 6 \mathrm{~h}$ later. Accordingly, 

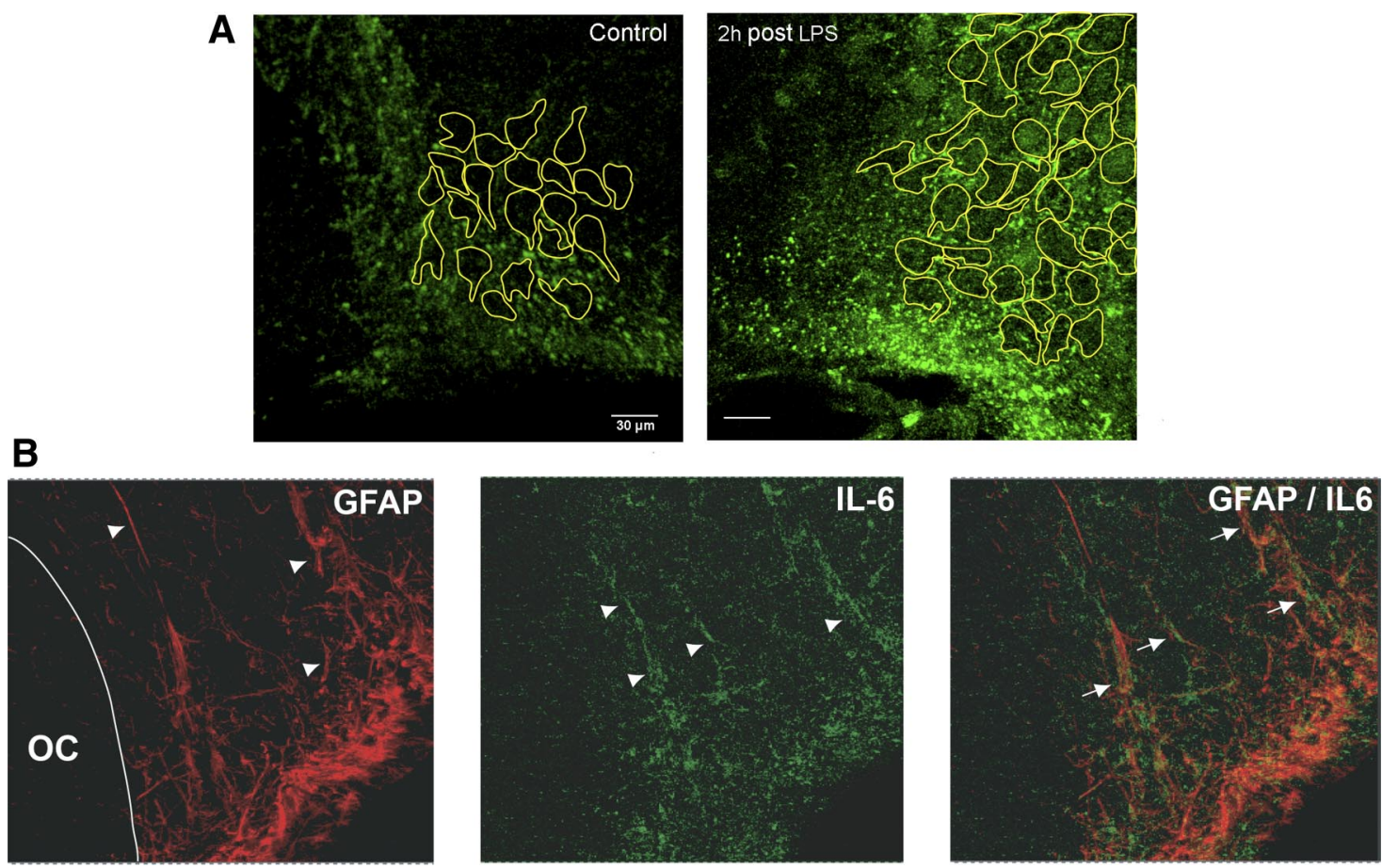

Fig. 7. IL-6 protein expression is increased in SON in response to immune challenge and expressed by astrocytes. Rats were injected ip with PBS $(n=3)$ or LPS $(n=3)$ and euthanized $2 \mathrm{~h}$ later to perform single-fluorescent staining of IL-6 ( $A$; scale bar $=40 \mu \mathrm{m})$ or double-fluorescent staining of IL-6 and glial fibrillary acidic protein (GFAP) in the SON of LPS-treated rats $(B$; scale bar $=30 \mu \mathrm{m})$, followed by analysis on a confocal microscope.

$1 \mathrm{~h}$ after LPS treatment, we detected 1 ) Fos immunoreactivity in cell nuclei located in the ventral part of SON, known to contain mainly AVP neurons, and 2) an increase in plasma [AVP]. This release was maintained at a high level $\leq 6 \mathrm{~h}$ post-LPS and was coupled to a decrease in diuresis. These results corroborate precise previous data reporting l) an increase in $c$-fos mRNA expression in rat SON $2 \mathrm{~h}$ after ip LPS that vanished $6 \mathrm{~h}$ later $(41,42), 2)$ an increase in Fos protein expression in rat AVP neurons $2 \mathrm{~h}$ after LPS ip injection (35, 51 , and 3) an increase in rat plasma [AVP] from 1 to $3 \mathrm{~h}$ after LPS $(19,25)$. The differences in the kinetics of changes between our results and those of the literature may be due to the differences in doses and routes of LPS injection. In vivo electrophysiological recordings in anesthetized rats confirmed the rapid activation of AVP neurons in SON with significant changes occurring as early as $1 \mathrm{~h}$ post-LPS. For all AVP neurons tested, the phasic pattern was strengthened with a clear increase in the duration of active periods and/or decrease in the duration of silences, an effect translated by an increase in the mean frequency, $F$, and in the activity quotient, $Q$. Such changes are known to increase AVP release (21), as our present data also attest.
A

Fig. 8. IL-6 neutralizing antibodies blocked LPS-induced AVP neurons electrical activation. Adult rats were anesthetized, and AVP neuron electrical activity was recorded by electrophysiology. A: discontinuous recordings showing the evolution of AVP neuron electrical activity before (control) and after intracerebroventricular (icv) injection of IL-6 neutralizing antibodies. Forty minutes after the IL-6 neutralizing antibody treatment, LPS was ip injected and the electrical activity of the same AVP neuron further recorded for $1 \mathrm{~h}$. The frequency, $F$, is expressed in spikes/s. $B$ : histograms of the averaged values of the frequency of discharge $F(n=6$, repeated-measures ANOVA; $* P<0.05$, IL-6 neutralizing antibodies vs. control) and the activity quotient $Q(n=6$, repeated-measures ANOVA; $* P<$ 0.001 , IL-6 neutralizing antibodies vs. control). Each neuron was its own control.
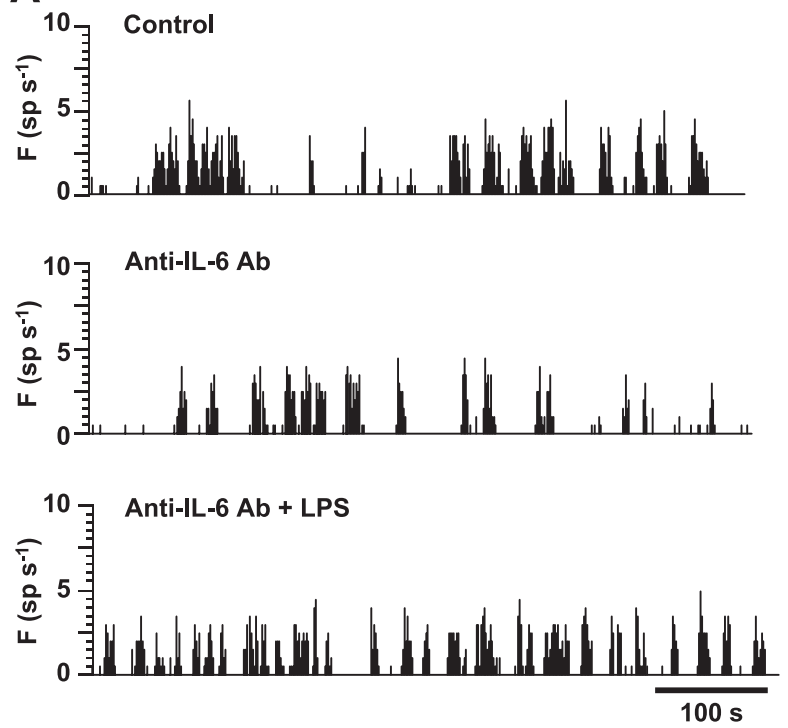

B
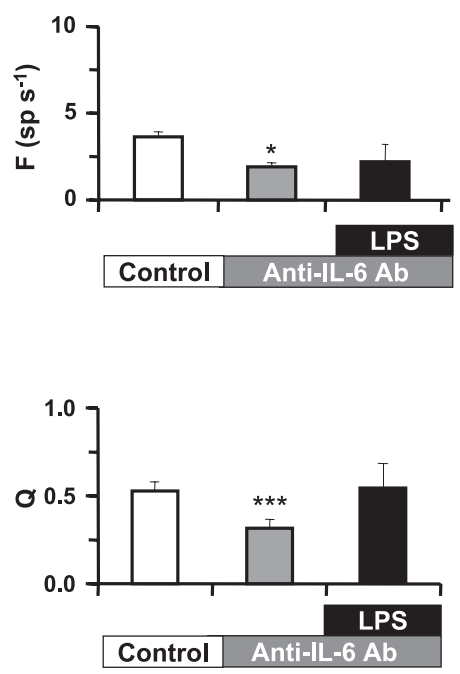
A
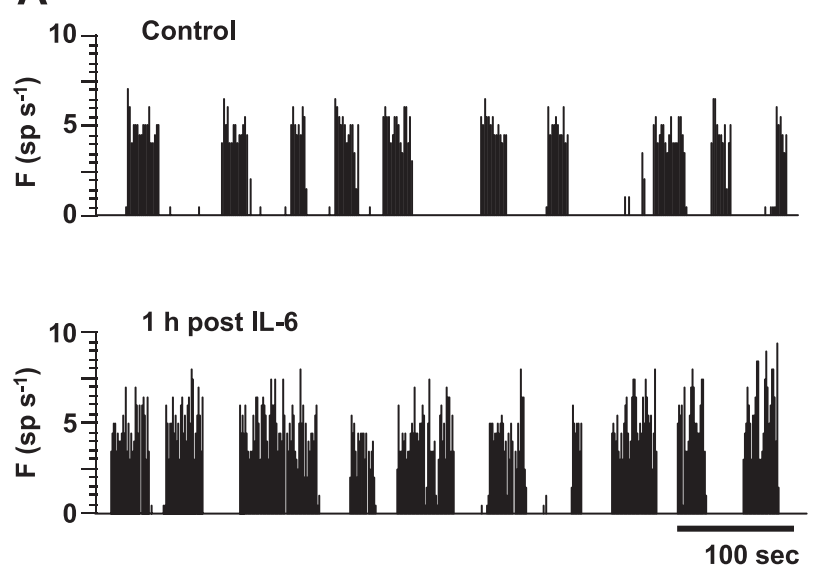

B
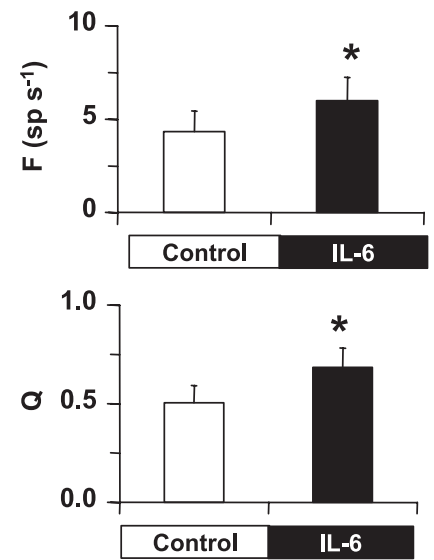

Fig. 9. Brain injection of IL-6 increases electrical activity of AVP neurons. Adult rats were anesthetized, and AVP neuron electrical activity was recorded by electrophysiology in SON. A: discontinuous recordings showing the evolution of an AVP neuron electrical activity recorded before and $1 \mathrm{~h}$ after icv IL-6 injection. The frequency, $F$, is expressed in spikes/s. $B$ : histograms of the averaged values of the frequency of discharge, $F(n=5$, repeated-measures ANOVA; $* P<0.05)$, and the activity quotient, $Q(n=5$, repeatedmeasures ANOVA; $* P<0.05)$. Each neuron was its own control.
The LPS Increases the Activity of AVP Neuron Independently of the Plasma Osmolality and the Blood Pressure

Because the increases in plasma [AVP], metabolic activity (c-fos expression), and electrical activity of AVP neurons (reinforcement of their phasic pattern) occurred as early as 30 min delay, we then determined the physiological factors that could be responsible for this early activation. Because AVP neurons are highly osmo-, volo-, and barosensitive (reviewed in Ref. 9), we first checked whether LPS treatment could induce an increase in plasma osmolality or a decrease in blood pressure that could be responsible for their activation. In the present study, and similarly to Kasting et al. (25), we did not detect any change in plasma osmolality during the first $18 \mathrm{~h}$ post-LPS injection. As to the blood pressure, LPS peripheral injection has been shown to induce a hypotension (25), and in rats, both systolic and diastolic blood pressures significantly decreased at different time points after LPS administration (52). In our anesthetized rats, we observed a clear increase in blood pressure, which developed gradually during the first 30 min post-LPS and lasted around $1 \mathrm{~h}$ before returning to control values. This hypertension may result from the increase in plasma release of key vasoregulators like angiotensin, renin, and endothelin in response to LPS. However, the increases in plasma renin, endothelin-1, and angiotensin II levels have been shown to occur much later, peaking at 2,3 , and $6-8 \mathrm{~h}$ post-LPS, respectively $(32,52)$. On the reverse, the early increase in AVP plasma release might sustain the progressive increase in blood pressure observed. The fact that AVP neuron activity and plasma [AVP] still continued to increase whereas blood pressure returned to control values suggests the involvement of other mechanisms regulating arterial pressure that remain to be elucidated. However, our data bring clear evidence that plasma osmolality and blood pressure are not involved in the LPS-induced early activation of AVP neurons. Thereafter, we searched for the central molecular factors susceptible to underlie this early activation.

\section{Involvement of Brain IL-6 in the Early Activation of AVP Neurons in Response to an Immune Challenge}

We studied the expression of several inflammatory mediators likely to affect directly the activity of AVP neurons after
LPS treatment, in particular prostanoids like $\mathrm{PG}_{-} \mathrm{E}_{2}(3,15,31)$ and cytokines such as IL-1 $\beta$, IL-6, or $\mathrm{TNF} \alpha(11,13,23)$. PG- $E_{2}$ could mediate this neuronal activation since PG receptors are expressed by SON neurons. Their activation is known to activate nonselective cation channels, to induce membrane depolarization, and to increase firing rate (47). However, in our study, PG-E 2 cannot underlie the early AVP neuron activation since its mRNA expression increased $3 \mathrm{~h}$ post-LPS. Among the main cytokines released during the immune challenge (30), IL-1 $\beta$ expressed mainly by microglial cells appeared to be a good candidate; it stimulates AVP release (29) by activating SON neurons (33), which are known to express type 1 IL-1 receptors (IL-1R1) (10). More precisely, IL-1 $\beta$ depolarizes magnocellular neurons in the PVN as a result of $P G-E_{2^{-}}$ mediated activation of a nonspecific cationic channel (14), an effect mediated via an IL-1R1-mediated induction of PG-E 2 synthesis and $\mathrm{EP}_{4}$ receptor-dependent autocrine upregulation of the nonselective cation conductance that underlies osmoreception (5). However, IL-1 $\beta$ mRNA expression increased in the SON only $3 \mathrm{~h}$ post-LPS and consequently cannot underlie the early activation of AVP neurons. The same applies for $\mathrm{TNF} \alpha$, which is known to provoke a marked sensitization of c-fos staining within the PVN and SON (22), since the expression of TNF $\alpha$ mRNA in the SON increased only $3 \mathrm{~h}$ post-LPS. Finally, the last putative cytokine tested, IL-6, appeared to be the best candidate to mediate the LPS-induced early activation of AVP neurons, since the expression of IL- 6 mRNA increased as early as 30 min post-LPS. Using pharmacological treatments during electrophysiological recordings of AVP neurons in anesthetized adult rats, we demonstrated that icv injection of IL-6 activated AVP phasic neurons similarly to LPS treatment, whereas the neutralizing anti-IL-6 antibodies had inhibitory effect, thus revealing that the basal expression of IL-6 in the SON underlies part of the basal phasic activity of AVP neurons. Finally, prior brain injection of anti-IL-6 antibodies prevented the LPS-induced activation of AVP neurons, attesting that IL-6 is involved in the earlier activation of AVP neurons in response to an immune challenge in rat. In situ hybridization and immunocytochemistry studies have shown that IL-6 is robustly expressed in the SON and the PVN of the hypothalamus (16). As to its cellular origin, IL-6 has been described to be expressed mainly by AVP neurons under basal 
conditions or after dehydration $(16,20)$ or by astrocytes during the LPS-induced challenge and in aged rats (40). Whatever the cell origin of IL-6, the IL-6 receptors are expressed by AVPneurophysin-immunoreactive neurons (40), which suggests a direct regulation by IL-6 of AVP neuron activity. Furthermore, these two localizations are not incompatible. The direct regulation of AVP neuron activity by IL-6 may result from either a neuronal autocontrol mechanism (short-loop feedback release of IL-6 from soma or dendrites of AVP neurons) or a glioneuronal volumic transmission of IL-6, both of which could be blocked by the injection of IL-6 antibodies. On the other hand, the LPS-induced sustained activation of AVP neurons might be ensured mainly by astrocytic IL-6, since LPS injection is well known to induce activation of glial cells that consequently express cytokines $(11,13,23)$. Although it is very interesting and enlarges our concepts of neuronal regulation by cytokines, such a dual control mechanism remains to be confirmed.

In conclusion, our data give evidence for the involvement of IL-6 in the onset activation of AVP during an immune challenge. The early peak of AVP release induced antidiuresis, a physiological process that could be useful in preventing a possible water dysregulation that may result from LPS-induced fever or inflammatory process. Furthermore, our results suggest a delayed role for IL- $1 \beta, \mathrm{TNF} \alpha$, and the prostanoid PG- $E_{2}$, which are expressed much later than IL-6 and likely underlie the sustained activation of AVP neurons for several hours. Studies are in progress to discover the role ensured by these molecules.

\section{ACKNOWLEDGMENTS}

The help of Philippe Legros and Christel Poujol is acknowledged. The microscopy was done in the PICIN imaging center of the Neurosciences Institute of the University of Bordeaux II.

\section{GRANTS}

This work was supported by the Fondation pour la Recherche Médicale (contract LLC20051005102) and by Groupement d'intérêt Scientifique Institut National de la Santé et de la Recherche Médicale "Longévité et vieillissement" (contract no. GISL0412).

\section{REFERENCES}

1. Albe-Fessard D, Libouban S, Stutinsky F. Atlas Stéréotaxique du Diencéphale du Rat Blanc. Paris: Centre National de la Recherche Scientifique, 1966.

2. Armstrong WE. Morphological and electrophysiological classification of hypothalamic supraoptic neurons. Prog Neurobiol 47: 291-339, 1995.

3. Blatteis CM, Quan N, Xin L, Ungar AL. Neuromodulation of acutephase responses to interleukin-6 in guinea pigs. Brain Res Bull 25: 895-901, 1990.

4. Brooks AN, Gibson F. Prostaglandin E2 enhances AVP-stimulated but not CRF-stimulated ACTH secretion from cultured fetal sheep pituitary cells. J Endocrinol 132: 33-38, 1992.

5. Chakfe Y, Zhang Z, Bourque CW. IL-1 $\beta$ directly excites isolated rat supraoptic neurons via upregulation of the osmosensory cation current. Am J Physiol Regul Integr Comp Physiol 290: R1183-R1190, 2006.

6. Churchill L, Taishi P, Wang M, Brandt J, Cearley C, Rehman A, Krueger JM. Brain distribution of cytokine mRNA induced by systemic administration of interleukin-1beta or tumor necrosis factor alpha. Brain Res 1120: 64-73, 2006.

7. Cunningham ET Jr, Sawchenko PE. Reflex control of magnocellular vasopressin and oxytocin secretion. Trends Neurosci 14: 406-411, 1991.

8. Curran T, Morgan JI. Memories of fos. Bioessays 7: 255-258, 1987.

9. den Ouden DT, Meinders AE. Vasopressin: physiology and clinical use in patients with vasodilatory shock: a review. Neth J Med 63: 4-13, 2005.

10. Diana A, Van Dam AM, Winblad B, Schultzberg M. Co-localization of interleukin-1 receptor type I and interleukin-1 receptor antagonist with vasopressin in magnocellular neurons of the paraventricular and supraoptic nuclei of the rat hypothalamus. Neuroscience 89: 137-147, 1999.

11. Dong Y, Benveniste EN. Immune function of astrocytes. Glia 36: 180190, 2001.

12. Dunn AJ. Effects of cytokines and infections on brain neurochemistry. Clin Neurosci Res 6: 52-68, 2006.

13. Farina C, Aloisi F, Meinl E. Astrocytes are active players in cerebral innate immunity. Trends Immunol 28: 138-145, 2007.

14. Ferri CC, Yuill EA, Ferguson AV. Interleukin-1beta depolarizes magnocellular neurons in the paraventricular nucleus of the hypothalamus through prostaglandin-mediated activation of a non selective cationic conductance. Regul Pept 129: 63-71, 2005.

15. Gatti S, Bartfai T. Induction of tumor necrosis factor-alpha mRNA in the brain after peripheral endotoxin treatment: comparison with interleukin-1 family and interleukin-6. Brain Res 624: 291-294, 1993.

16. Ghorbel MT, Sharman G, Leroux M, Barrett T, Donovan DM, Becker KG, Murphy D. Microarray analysis reveals interleukin-6 as a novel secretory product of the hypothalamo-neurohypophyseal system. J Biol Chem 278: 19280-19285, 2003.

17. Gilbert RP. Mechanisms of the hemodynamic effects of endotoxin. Physiol Rev 40: 245-279, 1960.

18. Giusti-Paiva A, Branco LG, de Castro M, Antunes-Rodrigues J, Carnio EC. Role of nitric oxide in thermoregulation during septic shock: involvement of vasopressin. Pflugers Arch 447: 175-180, 2003.

19. Giusti-Paiva A, Branco LG, de Castro M, Antunes-Rodrigues J, Carnio EC. Role of nitric oxide in thermoregulation during septic shock: involvement of vasopressin. Pflügers Arch 447: 175-180, 2003.

20. Gonzalez-Hernandez T, Afonso-Oramas D, Cruz-Muros I, BarrosoChinea P, Abreu P, del Mar Perez-Delgado M, Rancel-Torres N, del Carmen Gonzalez M. Interleukin-6 and nitric oxide synthase expression in the vasopressin and corticotrophin-releasing factor systems of the rat hypothalamus. J Histochem Cytochem 54: 427-441, 2006.

21. Gouzènes L, Desarmenien MG, Hussy N, Richard P, Moos FC. Vasopressin regularizes the phasic firing pattern of rat hypothalamic magnocellular vasopressin neurons. J Neurosci 18: 1879-1885, 1998.

22. Hayley S, Staines W, Merali Z, Anisman H. Time-dependent sensitization of corticotropin-releasing hormone, arginine vasopressin and c-fos immunoreactivity within the mouse brain in response to tumor necrosis factor-alpha. Neuroscience 106: 137-148, 2001.

23. Johann S, Kampmann E, Denecke B, Arnold S, Kipp M, Mey J, Beyer C. Expression of enzymes involved in the prostanoid metabolism by cortical astrocytes after LPS-induced inflammation. J Mol Neurosci 34: $177-185,2008$.

24. Kasting NW. Characteristics of body temperature, vasopressin, and oxytocin responses to endotoxin in the rat. Can J Physiol Pharmacol 64: 1575-1578, 1986.

25. Kasting NW, Mazurek MF, Martin JB. Endotoxin increases vasopressin release independently of known physiological stimuli. Am J Physiol Endocrinol Metab 248: E420-E424, 1985.

26. Knepper MA, Nielsen S, Chou CL, DiGiovanni SR. Mechanism of vasopressin action in the renal collecting duct. Semin Nephrol 14: 302321, 1994.

27. Konsman JP, Kelley K, Dantzer R. Temporal and spatial relationships between lipopolysaccharide-induced expression of Fos, interleukin-1beta and inducible nitric oxide synthase in rat brain. Neuroscience 89: 535-548, 1999.

28. Konsman JP, Vigues S, Mackerlova L, Bristow A, Blomqvist A. Rat brain vascular distribution of interleukin-1 type-1 receptor immunoreactivity: relationship to patterns of inducible cyclooxygenase expression by peripheral inflammatory stimuli. J Comp Neurol 472: 113-129, 2004.

29. Landgraf R, Neumann I, Holsboer F, Pittman QJ. Interleukin-1 beta stimulates both central and peripheral release of vasopressin and oxytocin in the rat. Eur J Neurosci 7: 592-598, 1995.

30. Laskin DL, Laskin JD. Role of macrophages and inflammatory mediators in chemically induced toxicity. Toxicology 160: 111-118, 2001.

31. Laye S, Parnet P, Goujon E, Dantzer R. Peripheral administration of lipopolysaccharide induces the expression of cytokine transcripts in the brain and pituitary of mice. Brain Res 27: 157-162, 1994.

32. Li JL, Yin CH, Wang C, Wen Y, Zhang SW, Wang BE. [Study on changes in circulatory renin-angiotensin system in rats with endotoxemia]. Zhongguo Wei Zhong Bing Ji Jiu Yi Xue 18: 92-95, 2006.

33. Li Z, Inenage K, Kawano S, Kannan H, Yamashita H. Interleukin-1 beta directly excites hypothalamic supraoptic neurons in rats in vitro. Neuroreport 3: 91-93, 1992. 
34. Mastorakos G, Weber JS, Magiakou MA, Gunn H, Chrousos GP. Hypothalamic-pituitary-adrenal axis activation and stimulation of systemic vasopressin secretion by recombinant interleukin-6 in humans: potential implications for the syndrome of inappropriate vasopressin secretion. J Clin Endocrinol Metab 79: 934-939, 1994.

35. Matsunaga W, Miyata S, Takamata A, Bun H, Nakashima T, Kiyohara T. LPS-induced Fos expression in oxytocin and vasopressin neurons of the rat hypothalamus. Brain Res 858: 9-18, 2000.

36. McKinley MJ, Mathai ML, McAllen RM, McClear RC, Miselis RR, Pennington GL, Vivas L, Wade JD, Oldfield BJ. Vasopressin secretion: osmotic and hormonal regulation by the lamina terminalis. $J$ Neuroendocrinol 16: 340-347, 2004.

37. Michelini LC, Morris M. Endogenous vasopressin modulates the cardiovascular responses to exercise. Ann NY Acad Sci 897: 198-211, 1999.

38. Morgan JI, Curran T. Stimulus-transcription coupling in neurons: role of cellular immediate-early genes. Trends Neurosci 12: 459-462, 1989.

39. Naito Y, Fukata J, Shindo K, Ebisui O, Murakami N, Tominaga T, Nakai Y, Mori K, Kasting NW, Imura H. Effects of interleukins on plasma arginine vasopressin and oxytocin levels in conscious, freely moving rats. Biochem Biophys Res Commun 174: 1189-1195, 1991.

40. Palin K, Moreau ML, Orcel H, Duvoid-Guillou A, Rabié A, Kelley KW, Moos F. Age-impaired fluid homeostasis depends on the balance of IL-6/IGF-I in the rat supraoptic nuclei. Neurobiol Aging. In press.

41. Quan N, He L, Lai W. Endothelial activation is an intermediate step for peripheral lipopolysaccharide induced activation of paraventricular nucleus. Brain Res Bull 59: 447-452, 2003.

42. Rivest S, Laflamme N. Neuronal activity and neuropeptide gene transcription in the brains of immune-challenged rats. $J$ Neuroendocrinol 7: 501-525, 1995.

43. Sapolsky R, Rivier C, Yamamoto G, Plotsky P, Vale W. Interleukin-1 stimulates the secretion of hypothalamic corticotropin-releasing factor. Science 238: 522-524, 1987.
44. Shibuya I, Setiadji SV, Ibrahim N, Harayama N, Maruyama T, Ueta Y, Yamashita H. Involvement of postsynaptic EP4 and presynaptic EP3 receptors in actions of prostaglandin E2 in rat supraoptic neurones. J Neuroendocrinol 14: 64-72, 2002.

45. Smith PK, Krohn RI, Hermanson GT, Mallia AK, Gartner FH, Provenzano MD, Fujimoto EK, Goeke NM, Olson BJ, Klenk DC. Measurement of protein using bicinchoninic acid. Anal Biochem 150: $76-85,1985$.

46. Stricker EM, Verbalis JG. Interaction of osmotic and volume stimuli in regulation of neurohypophyseal secretion in rats. Am J Physiol Regul Integr Comp Physiol 250: R267-R275, 1986.

47. Sutarmo Setiadji V, Shibuya I, Kabashima N, Ibrahim N, Harayama N, Ueta Y, Yamashita H. Actions of prostaglandin E2 on rat supraoptic neurones. J Neuroendocrinol 10: 927-936, 1998.

48. Wakerly JB, Poulain DA, Dyball RE, Cross BA. Activity of phasic neurosecretory cells during haemorrhage. Nature 258: 82-84, 1975.

49. Wang X, Zhang XJ, Tan QR, Ju G, Wang BR. Different signaling molecules responsible for IL-1beta-induced oxytocinergic and vasopressinergic neuron activation in the hypothalamic paraventricular nucleus of the rat. Neurochem Int 48: 312-317, 2006.

50. Xu S, Guo S, Jiang X, Umezawa T, Hisamitsu T. The role of norepinephrine and nitric oxide in activities of rat arginine vasopressin neurons in response to immune challenge. Neurosci Lett 383: 231-235, 2005

51. Xu S, Guo S, Jiang X, Yin Q, Umezawa T, Hisamitsu T. Effect of indomethacin on the c-fos expression in AVP and TH neurons in rat brain induced by lipopolysaccharide. Brain Res 966: 13-18, 2003.

52. Yamaguchi N, Jesmin S, Zaedi S, Shimojo N, Maeda S, Gando S, Koyama A, Miyauchi T. Time-dependent expression of renal vasoregulatory molecules in LPS-induced endotoxemia in rat. Peptides 27: 2258-2270, 2006.

53. Zhang J, Rivest S. Distribution, regulation and colocalization of the genes encoding the EP2- and EP4-PGE2 receptors in the rat brain and neuronal responses to systemic inflammation. Eur J Neurosci 11: 2651-2668, 1999. 